\title{
The Inventory of Ferns at Sambas Botanical Garden as A Learning Resource of Pteridophyta for High School Level
}

\author{
Nuri Dewi Muldayanti ${ }^{*}$, Arif Didik Kurniawan ${ }^{1}$, Agus Setiadi ${ }^{1}$ \\ ${ }^{1}$ Universitas Muhammadiyah Pontianak, Indonesia \\ nuri.dewi@unmuhpnk.ac.id
}

\begin{abstract}
Sambas Regency has regional potentials such as Sambas Botanical Garden with a diversity of ferns. However, the diversity of the ferns has not been used and explored as a learning resource as it has not been well documented. This study aimed to investigate the types of terrestrial ferns found in Sambas Botanical Garden and their potential as a source of learning in the Pteridophyta course. This study used a qualitative method with an exploratory approach. The data source in this study were ferns found in Sambas Botanical Garden and Sambas Botanical Garden master plan document. The data collection techniques used were observation, sampling, identification of plants, and interviews. The data collection tools were observation sheets, sampling equipment, plant identification guides, and interview sheets. The data analysis techniques were data reduction, data presentation, and verification. The results showed there were 9 species included in 7 families. The Blechnaceae family included Blechnum orientale and Stenochlaena palustris species. The Pteridaceae family included the Pityrograma calomelanos species. The Thelypteridaceae family included the Thelypteris sp. and Thelypteris kunthii. The Gleicheniaceae family included the Dicranopteris linearis species. The Dryopteridaceae family included the Nephrolepis biserrata species. The Lycopodiales family included the Lycopodium clavatum species. The Dennstaedtiaceae family included the Lindsaea doryphora species. In other words, the results of the terrestrial ferns in Sambas Botanical Garden have fulfilled the requirements as the learning sources in the Pteridophyta sub material for the high school level. This can be proven by the clarity of the potential, the learning objectives, the objectives, the information revealed, the exploration guidelines, and the expected outcomes. Therefore, ferns diversity found in Sambas Botanical Garden is suitable to be used as the learning resources in the sub material of Pteridophyta.
\end{abstract}




\section{Introduction}

Act of the Republic of Indonesia on National Education System concerning curricula at all levels and types of education are developed with the principle of diversification per education units, regional potential, and students (Yulicahyani, 2017). This means that regional potential has an important role in the learning process as almost all subjects at school have a relationship with local potential. One of the subjects that correlate with this potential is Biology.

According to Yulicahyani (2017), Biology is one of the subjects that correlate to the environment as it discusses the natural phenomena that are systematically arranged based on the results of experiments and observations done by humans. The biology learning process will be more meaningful when the objects, the sources, and the teaching materials used are real and related to human life. Therefore, it is important to use and to explore regional potential as a learning source to provide active and participatory learning opportunities, as well as concrete learning experiences for students (Lusiana, 2015). In this case, one of the materials taught at the high school level in Biology class is Plant material.

Plant material is a material included in Biology class and it is taught at the tenth grade of an odd semester of 2013 curriculum. Plant material consists of several sub materials. One of which is Pteridophyta. In learning this sub material, students will be exposed by direct experiences of objects and daily life events. Thus, the materials provided are learned applicatively. By implementing environmental exposure, learning objectives that have been set by the teacher can be achieved maximally (Syamsudduha, 2012).

Unfortunately, the syllabus used by the teacher, by far, contained no correlation between local potential and the plant material. As a result, the students did not get the local potential-based material and they were not aware of this potential in their surroundings. Susilo (2015) states that the potential of local areas/regions has not been used optimally in Biology learning activities, while the exploitation of regional potential is one of the characteristics in curriculum development.

According to Lusiana (2015), the diverse source of learning around student life has not been used optimally in the teaching-learning process. Even though a lot of learning sources, such as a library, surroundings, objects, and so on, can be used in the teaching-learning process, many high school teachers prefer to use textbooks as the only learning resources.

The environment covers regional potential which has specific resources possessed by an area. They include natural and human resources, geographical, historical, and cultural potential. The potential area used as the learning sources provide students with easiness and motivation in learning so that the students can easily get the information, the knowledge, the experience, and the skills in the teaching-learning process (Dahlia, 2016). In this way, the potential area used is Sambas Botanical Garden.

Sambas Botanical Garden is the only botanical garden in West Kalimantan Province which will become a conservation area for plants and an area of education and research, as well as a green open tourist area (LIPI: 2008). It has various diversity of plants and animals which is covered by secondary forest vegetation and shrubs. This is a lowland forest with a swamp and riparian forest. This vegetation condition becomes a potential habitat that allows the growth of ferns. As mentioned by Lusiana (2015) that vegetation which includes shrubs and large trees is a suitable habitat for the life of ferns or Pteridophyta.

By this time, there has been no research on the diversity of ferns in the Sambas Botanical Garden. That is why diversity hasn't been well documented. Similarly, school as the local center of education has not explored and used this diversity, to support the learning process and to achieve the learning goals, as the learning resources. Therefore, it is important to collect information about ferns and to use 
them as the learning resources by conducting an inventory activity. Shofiana (2017) describes plant inventory activity as an activity that includes identification of species, identification of the number of the species, and identification of the number of the individuals of each type. The identification stage is done to determine the appropriate names and places of the plants in the classification system (determination). This study used the inventory activity of ferns in the Sambas Botanical Garden to determine their potential as the learning resources in the sub material of Pteridophyta for high school level students.

\section{Method}

This study used a qualitative method of exploration approach. The samples were selected by exploring the potential area of the ecosystem or the ferns vegetation at the Sambas Botanical Garden. The data collection techniques and tools used were: 1) Observation, this activity aims to observe and detect directly the types of ferns in the research location, 2) Sampling, this activity aims to retrieve the fern sauce found during the study exploration around the research location to be used as a herbarium, 3) Plant Identification, this activity aims to identify the types of ferns found, and 4) Interview, this activity aims to find information related to the use of the Sambas Botanical Garden as a learning resource. The data were analyzed in three stages, namely 1) data reduction, where this stage selects ferns including terrestrial ferns and summarizes the results of interviews with biology subject teachers related to regional potential with learning resources, 2) data presentation, at this stage, namely organizing All data obtained through the reduction stage where it is adjusted between the ferns found for learning, and 3) verification, at this stage, that is, if the data presented is good, a credible conclusion can be made from the results of the research conducted (Sugiyono, 2014).

\section{Results and Discussion}

Biology class is a course that is closely related to the surroundings. The development and the implementation of the 2013 curriculum are based on the content standards and the graduate competency standards. Using local potential, the environment becomes an important source in the teaching-learning process, particularly in Biology subject. The environment exploration provides direct experience for students to develop competencies in exploring and understanding the natural environment scientifically (Dahlia, 2016). In this matter, the natural potential used as the learning source is Sambas Botanical Garden.

Learning resources are materials, objects, or people that teachers use to help to meet the expectations for learning (Abdullah, 2012). Additionally, Mulyasa (2011) emphasizes learning resources as all things that can provide ease of learning, so that students can get information, knowledge, experience, and skills for their direct and indirect future necessities. Learning resources play a meaningful function in learning. They not only complete and enrich students' knowledge but also increase students' learning activity and creativity. In this study, Pteridophyta is the selected material that provides local potential (ferns) of Sambas Botanical garden.

The inventory activities of ferns vegetation in Sambas Botanical Garden were conducted by exploring the entire area that represented the types of ferns studied. The results of data analysis found 9 (nine) types of terrestrial ferns that could be used as learning resources. It is based on the theory that learning resources obtained from the environment should meet several conditions for learning resources. According to Suratsih (2010), results of a study can be used as learning resources as long as they contain 1) the clarity of potential 2) the suitability to the learning objectives 3) the clarity of the objectives 4) the clarity of the information revealed 5) the clarity of the exploration guidelines, 
and 6) the clarity of the expected acquisition. Further, the explanation of the potential of ferns vegetation in Sambas Botanical Garden is described as follows:

The Clarity of the Potentials. The magnitude of the potential of an object and its problems are used as the learning resource dealing with the problems in Biology class based on the concept of the curriculum. The potential of an object is determined by the availability of the object and the problem that can be revealed to show the facts and concepts from the results of the research that must be achieved in the curriculum. In the inventory activity, the objects observed were the types of terrestrial ferns found in the Sambas Botanical Garden. The selection is done to determine the specimens that will be identified and compared to epiphytic ferns. The results of this phase found 9 species of terrestrial ferns.

The Information Suitability to the Learning Objectives. Based on the regulation of the minister of Education of the Republic of Indonesia No. 41 of 2007, regarding the standard processes for primary and secondary education, learning objectives describe the process and learning outcomes that are expected to be achieved by students under basic competencies. The purpose of learning in the curriculum plays an important role in the learning process, which is to direct all learning activities. The suitability, in this study, refers to the suitability of the results of the ferns inventory and the learning objectives stated in the Lesson Plan of Biology class. The results of the analysis showed the suitability of the ferns inventory and the learning objectives of the Pteridophyta sub material.

\begin{tabular}{lc}
\hline \multicolumn{1}{c}{ Learning Objectives } & \multicolumn{2}{c}{$\begin{array}{c}\text { The Suitability to The } \\
\text { Curriculum of 2013 }\end{array}$} \\
\cline { 2 - 2 } & Suitable Unsuitable \\
\hline $\begin{array}{l}\text { Describing the characteristics of ferns morphologically } \\
\begin{array}{l}\text { Classifying the ferns into divisions based on the } \\
\text { observed characteristics }\end{array}\end{array}$ & $\sqrt{ }$ \\
\hline
\end{tabular}

Table 1: The Suitability to Learning Objectives

The Clarity of the Target (Goals). The learning process does not always depend on the teacher (educator) as the classroom manager. This is based on the nature of the learning process that requires interaction between students (subjects) and the object being studied (Suhardi, 2012). The clarity of target (goals) in a study becomes an important point as it determines the teaching-learning process and the interaction during the learning process. The clarity includes the clarity of the material (object) and its purposes (subject). Specifically, the clarity of Plantae material.

The Clarity of the Information Revealed. The clarity of the information is obtained from the results of the study in the form of processes and products. This study used a cruise method to find terrestrial ferns. Cruise method is a method that is done by exploring the entire area that represents the type of ecosystem in the area being studied (Betty, 2015). The products resulted from the facts and the scientific concepts of the study. The products were 9 types of ferns in Sambas Botanical Garden. The clarity, then, becomes one of the requirements of the learning sources.

Clarity of the Exploration Guidelines. Exploration guidelines are work procedures in conducting the research. The procedures involve the determination of the research objects, tools, and materials, observation, sampling, and identification of plants. The exploration guidelines that can be used as the learning resources by the students are the guidelines that contain clear and procedural implementation. The exploration of ferns is conducted by using the exploration method in the ferns area by referring to the journal (Betty, 2015). This method does not require a specific plot or size of the area being studied. It only requires exploration activities. Before the exploration was conducted, the researcher discussed the potential areas/zones of ferns with the manager of the Sambas Botanical Garde. After the area is identified, the researcher started to select the sample of the ferns. The selection was done by directly uprooting or pulling the ferns to be identified and dried. 
The Clarity of the Expected Acquisition. The Clarity of the expected acquisition can be achieved when the results of the observation successfully assist the students in accomplishing the learning goals. The accomplishment is indicated by the students' enhancement of the cognitive, affective, and psychomotor aspects.

\section{Conclusion}

From the findings, it is concluded that there are 7 families, consisting of 9 species, of ferns found in Sambas Botanical Garden. The results of this study also indicate that terrestrial ferns found in Sambas Botanical Garden are potential as the learning resources for the Pteridophyta sub material for the high school level.

\section{References}

Abdullah R. 2012. Pembelajaran Berbasis Pemanfaatan Sumber Belajar. Jurnal Ilmiah DIDAKTIKA. XII(2): 216-231.

Betty. J, Linda. R and Lovadi. I 2015. Inventarisasi Jenis Paku-Pakuan (Pteridophyta) Terestrial di Hutan Dusun Tauk Kecamatan Air Besar Kabupaten Landak. In Bahasa. Jurnal Protobiont. 4: 94102.

Dahlia, Ibrohim and Mahanal. S. 2016. Pemanfaatan Potensi Hutan Wisata Baning sebagai Sumber Belajar Interaksi Mahluk Hidup dengan Lingkungan Di SMP. In Bahasa. Prosiding Semnas Pend. IPA Pascasarjana UM. Malang.

LIPI. 2008. Master Plan Kebun Raya Sambas Kalimantan Barat. Pemerintah Kabupaten Sambas Provinsi Kalimantan Barat.

Lusiana. N, Prihanta. N, and Rahardjanto. A. 2015. Pemanfaatan Pteridophyta Kawasan Hutan Pacet Taman Hutan Raya (Tahura) Raden Soerjo Kecamatan Pacet Kabupaten Mojokerto sebagai Sumber Belajar Biologi SMA. In Bahasa. Jurnal Pendidikan Biologi Indonesia. 1(1): 169-176.

Mulyasa. 2011. Kurikulum Berbasis Kompetensi, Konsep, Karakteristik dan Implementasi. In Bahasa. Bandung: PT Remaja Rosdakarya

Shofiana W. 2017. Inventarisasi Jenis-Jenis Tumbuhan Epifit di Kebun Biologi FMIPA UNY. In Bahasa. Jurnal Prodi Biologi. 6(2): 121-130.

Sugiyono. 2014. Metode Penelitian Pendidikan. In Bahasa. Bandung: Alfabeta.

Suhardi. 2012. Pengembangan Sumber Belajar Biologi. In Bahasa. Yogyakarta: Jurdik Biologi FMIPA UNY.

Suratsih. 2010. Pengembangan Modul Pembelajaran Biologi Berbasis Potensi Lokal dalam Kerangka Implementasi KTSP SMA di Yogyakarta. In Bahasa. Penelitian Unggulan UNY (Multi Tahun) Tahun Anggaran 2010.

Susilo MJ. 2015. Identifikasi Tumbuhan Berbiji (Spermatophyta) sebagai Materi Pembelajaran IPA-Biologi SMP Berbasis Potensi Lokal di Kawasan Pasir Psntsi Depok Kabupaten Bantul. In Bahasa. Prosiding Semnas Pend. Biologi UM. Malang.

Syamsudduha St and Rapi M. 2012. Penggunaan Lingkungan Sekolah sebagai Sumber Belajar dalam Meningkatkan Hasil Belajar Biologi. In Bahasa. Lentera Pendidikan. 15(1): 18-31.

Yulicahyani T, Prihandono T, and Lesmono DA. 2017. Pengembangan Modul Pembelajaran IPA Fisika Materi Suhu dan Pemuaian Berbasis Potensi Lokal "Kerajinan Logam Sayangan" untuk Siswa SMP di Kalibaru Banyuwangi. In Bahasa. Jurnal Pembelajaran Fisika. 6(2): 112-119. 